\title{
The Effect of Human Resource Management High Performance Work Practices on Organisational Outcomes: A Sri Lankan Perspective
}

\author{
Bhadra J.H. Arachchige \\ Senior Lecturer (Grade 1) \\ Department of HRM \\ University of Sri Jayewardenepura \\ Alan Robertson \\ Director of Studies (Business) \\ Nawaloka College of Higher Studies
}

\begin{abstract}
High performance work practices (HPWPs) in human resource management (HRM) are practices considered to contribute to higher levels of employee performance and organisational productivity. They may be implemented through a best practice (universalistic), best fit (contingent) or integrated bundling (configurational) strategy. This study explores the extent to which the level of adoption of HPWPs in HRM in Sri Lankan organisations influences selected measures of performance outcomes covering a broad spectrum of divisions, hierarchical levels and processes, including those reflecting the effectiveness of the HRM strategy. In addition, the relationship between seven groups of HPWPs and the selected performance outcomes are researched. The findings add support to existing research in a number of countries linking HPWP adoption with improved levels of performance outcomes. Although HPWPs influence some outcomes positively they also may have negative effects upon others. The results have indicated which practices most significantly impact upon different outcomes thereby providing organisational decision makers with a guide as to how HPWPs can be employed most effectively to achieve organisational objectives.
\end{abstract}

Key Words: High Performance Work Practices, Employee Performance, Organisational Productivity, Best Practice, Human Resource Management

\section{Introduction}

Over recent years researchers have given considerable attention to the impact of human resource management (HRM) on organisational performance (for example: Bowen and Ostroff, 2004; Browning, Edgar, Gray and Garrett, 2009; Collings, Demirbag, Mellahi and Tatoglu, 2010; Kroon, Van De Voorde and Timmers 2013; Kuvaas and Dysvik, 2010; Paauwe and Bosalie, 2003; Teagarden et al, 1995). A particular focus of their research has been the use of high performance work practices (HPWPs) in HRM which have been claimed to enhance productivity, thereby providing a competitive advantage for the relevant organization. There is considerable support for the adoption of HPWPs in HRM, led by the writings of Pfeffer (1998), although Marchington and Grugulis (2000) point out that generalized conclusions for such studies are difficult to accept due to differences in HRM practices being examined, methods used to collect data and types of respondents from whom information was gathered. There has, therefore, been both an enthusiasm for adoption of HPWPs by some organisations as well as a reluctance to "jump on the bandwagon" by others. 
Within the Sri Lankan business context HPWPs in HRM are being adopted in industries such as IT and telecommunications. Elsewhere there has been an apparent lack of awareness of the role that HRM may play in contributing towards business development with a resultant disinclination towards change in HRM structure and processes (Ranasinghe, 2013). As a result there is a need to understand whether HPWPs in HRM are in fact likely to contribute towards a higher level of performance outcomes in Sri Lankan organisations, both public and private. This study will therefore aim to address the following in the Sri Lankan organisational context:

1. Whether there is a significant variation in selected measures of performance between organisations with different levels of adoption of HPWPs in HRM.

2. Which areas of HPWPs have the most significant impact upon selected measures of organisational performance.

\section{HPWPs in HRM}

High performance work practices in human resource management are practices considered to contribute to higher levels of employee performance and organisational productivity. Three main approaches have been identified in relation to the adoption of HPWPs in HRM (Richardson and Thompson, 1999). The universalistic approach of "best practice" is based on the assumption that specific HRM strategies will, if adopted, enhance organisational performance. Popularised by Pfeffer $(1994 ; 1998)$ and widely supported by later studies, it is claimed that such practices will benefit most organisations, hence their ascription as universalistic. Pfeffer identified seven areas of best practice, namely: employment security, selective hiring, self managed teams/team working, high compensation contingent on organisational performance, extensive training, reduction of status differences and sharing information.

In contrast, "best fit", or the contingent approach, refers to the tailoring of HRM practices to the particular context of an organisation's strategies as well as the internal and external environments (Boxall and Purcell, 2008). It is founded on the belief that there is no universal panacea for HRM issues.

There is, however, an argument that individual practices should not be implemented as isolated entities and that they would be more effective if linked together in coherent and integrated "bundles" (Guest, Conway and Dewe, 2004). This configurational approach has the potential for additive, interactive and synergistic effects (Delery, 1998) as the components of each bundle support and mutually reinforce each other (Wood and de Menezes, 1998). While one may be inclined to intuitively prefer one of these approaches over the others, research findings are mixed in their support and criticism of each.

\section{Linking HPWP's in HRM to Organisational Performance}

The potential for a unique competitive advantage for an organization, unlike that from many other sources which are becoming easier to imitate, can reside in a high performance work force (Becker and Huselid, 1998), thereby providing a stimulus over the last 20 years for considerable research into the relationship between HRM practices and organisational performance. There has, however, been little consistency in relation to findings. To some 
extent this is the result of a lack of consensus in terms of what constitutes HRM practices, HPWPs and effective performance criteria as well as appropriate measures of each of these (Marchington and Wilkinson, 2005). While Pfeffer and others, as noted above, have claimed that HPWPs positively influence organisational performance, that more HPWPs leads to improved outcomes (Guest et al, 2000; Gould-Williams and Mohamed, 2010; Marchington and Grugulis, 2000) and that certain practices are more effective than others (West et al, 2002), there are contradictory studies that indicate an absence of evidence linking HPWPs in HRM to improved organisational performance (Guest et al, 2003). The findings are further complicated by the influence of contingent and contextual factors within organisations so that relationships evident in some may not be applicable to others (Browning, Edgar, Gray and Garrett, 2009). As a result there is little in the way of a theoretical base for the HRM organisational performance relationship (Boeslie et al, 2005; Guest, 1997).

In understanding the relationship between HRM and organisational performance it is necessary to identify the following: the HR practices that are likely to influence performance outcomes, the particular outcomes that can reflect that influence and, finally, the means by which outcomes can be measured.

Although 26 individual HR practices have been identified (Boselie et al, 2005) these have been grouped into a smaller number of more generalized categories. Popular classifications include the aforementioned by Pfeffer (1998) as well as Fey et al (2000) which contain seven and six items respectively. The best practice and best fit approaches to HPWP implementation normally imply one or two select practices. More recent literature is inclined to advocate multiple practices in configurational bundles, however the composition of the bundles varies between studies (Marchington and Wilkinson, 2005). The most common practices linked to HPWPs are recruitment and selection, training and development, performance management and teamwork (Browning et al, 2009; West et al, 2002; Kroon, Van De Voorde and Timmers, 2013; Gould-Williams and Mohamed, 2010) although information-sharing (Bruce, 2013; Kuvaas and Dysvik, 2010), employee empowerment (Kuvaas and Dysvik, 2010) and compensation (Bosalie et al, 2005; Boxall and Macky, 2009; Bruce, 2013) are also considered, but to a lesser extent. Of greater significance than which specific practices constitute the HPWP offering is the impact that they will have upon employees' behaviour and attitudes as these are the determinants of the extent to which they can influence performance outcomes (Park et al, 2003). Successful HPWPs should therefore include activities that promote positive perceptions of HR practice (Gould-Williams and Mohamed, 2010).

What constitutes performance outcomes has also been approached from a range of perspectives. Financial measures, particularly in relation to private enterprise organisations, remain a popular criterion. The choice of an appropriate type of financial statistic is a point of conjecture in many cases, however, and its comparative value needs to be understood in relation to external factors such as broad economic trends as well as industry and competitors' performance. Relevant research has tended to place an over-reliance on financial measures (Collings, Demirbag, Mellahi and Tatoglu, 2010). On the other hand, HR practices are, by definition, designed to add value to the human element of an organization, therefore outcomes related to employee characteristics need to be considered in conjunction with financial data. These include job satisfaction, intention to quit, job-related stress and prevalence of organisational citizenship behaviour (Gould-Williams and Mohamed, 2010; Brownin et al, 2009). Of particular importance are the elements that build the productive capacity of employees, succinctly expressed in the theoretical foundation of AMO (Boxall 
and Purcell, 2008 ): individual ability (Collings et al, 2010), motivation (Marchington and Grugulis, 2000) and the opportunity to perform (OU.S. General Accounting Office, 2000). They are strongly influenced by HR practices related to communication, social interaction, selection, training and development, compensation, empowerment and job design, and in unison serve to improve employee performance (Kroon and De Voorde, 2013). In addition to being a factor influencing the strength of HRM practices within an organization, the extent to which management practices and organization strategies link with HR can also be an indicator of its success in contributing to overall performance (Gould-Williams and Mohamed, 2010). This highlights the need to consider the impact of HR practice on each of individual, sectional (division, department, branch) and overall organisational outcomes when assessing its contribution to performance outcomes (Marchington and Grugulis, 2000).

Measurement of outcomes can be linked to conceptual foundations drawing on social interaction, resourcing, contingency frameworks and organisational strategy theories (Truss, 2001). In developing research models the direction of causality related to these concepts needs careful analysis to determine whether HRM practices impact upon performance or whether performance influences HRM practices (Marchington and Wilkinson, 2005). In addition, the early studies in this area which are referred to widely in the ensuing literature are most commonly based on large scale empirical data (Huselid, 1995; Wood and de Menezes, 1998; Guest et al, 2000a; 2000b; 2003). While these and other studies have indicated, often contradictory, patterns of relationships between HRM practices and performance there is a concern that the reasons for these are not fully understood, including the fact that they do not take into account informal practices and norms of behaviour (Truss, 2001) as well as external factors related to the economic, political, geographical, industrial and competitive environments.

The varied results obtained from studies of the HRM/performance outcomes relationship have been attributed to the different forms of measurement of both HRM practices as well as outcomes (Marchington and Wilkinson, 2005). It has also been argued that the evaluation of HPWPs requires input from all levels of an organization including senior management, HR professionals and other employees (Marchington and Grugulis, 2000). There has been a tendency to draw heavily from those considered to be closest to the sources of HRM practices and productivity information but the potential for these groups to be less objective in that the results may be seen as a reflection of their own performance.

\section{Research Model}

In order to find answers to the two questions posed in the introduction to this study the following need to be determined in relation to Sri Lankan organisations:

1. The level of variation in selected measures of performance between organisations with different levels of adoption of HPWPs in HRM.

The review of literature has indicated a number of performance outcomes which have been used in previous studies. Drawing upon these it was decided to focus on the following areas as indicators of organisational performance: financial (level of financial strength of the organization), productivity (improvement in productivity due to the introduction of HPWPs), management (management support for HRM practices; alignment with the management style of the organization), organisational characteristics 
(alignment of HPWPs with other organisational functions; level of innovativeness; level of risk-taking; competitive strength), employees (appropriateness of HR practices for the qualifications and experience of employees; level of involvement of non-management employees in developing HR practices); relevance to organisational characteristics (appropriateness of HR practices for location of the organization; appropriateness of HR practices for the size of the organization).

These outcomes were chosen because they covered a broad spectrum of organisational divisions, hierarchical levels and processes and in so doing provide an indication of which area of an organization are likely to be most impacted by the use of HPWPs in HRM.

2. The areas of HPWPs which have the most significant impact upon selected measures of organisational performance. The areas of HPWP practices are based upon Pfeffer's (1998) seven groups, namely: employment security, selective hiring, self managed teams/teamworking, high compensation contingent on organisational performance, extensive training, reduction of status differences and sharing information.

\section{Research Method}

\section{Data collection}

A total of 145 employees of Sri Lankan companies were contacted and requested to complete the questionnaire designed for data gathering for this study. Approximately half of those invited to participate were postgraduate business students of a Sri Lankan university, while the remainder were former students of the authors or their contacts in professional business associations. Hard copies of the questionnaires were given directly to the postgraduate students. Other responses were obtained by an online survey.

\section{Measurement development}

Data was gathered on the variables through a questionnaire, trialed initially with eight respondents and then modified in relation to the face validity of some questions. Responses related to performance outcomes, level of adoption of HPWPs and the strength of each of the seven groups of HPWPs were recorded on a seven-point Likert scale. Respondents were also requested to provide demographic details related to themselves and their organization recorded on nominal scales.

Completed questionnaires were received from respondents from 97 selected private and public organisations and the data was processed using SPSS. Statistical methods used included ANOVA to determine the level of variation in selected measures of performance between organisations with different levels of adoption of HPWPs in HRM, while the extent to which each of the HPWP groups influenced performance outcomes was indicated by multiple regression.

\section{Sample characteristics}

A total of 97 valid responses was obtained. Fifty seven percent of respondents were male and $43 \%$ female. The majority were from middle (27\%) and junior (37\%) management in their respective organisations of which $62 \%$ were large (greater than 500 employees) and well established (60\% more than 10 years). More than 17 classes of industry were represented in 
the survey, the most common being manufacturing, financial and educational. A summary of the sample demographics are presented in Table 1.

Table 1: Demographics

\begin{tabular}{|c|c|c|c|c|c|}
\hline \multicolumn{6}{|l|}{ RESPONDENTS } \\
\hline Gender & Frequency & Percent & Job Position & Frequency & Percent \\
\hline Male & 55 & 56.7 & Senior Manager & 6 & 6.2 \\
\hline \multirow[t]{3}{*}{ Female } & 42 & 43.3 & Middle Manager & 26 & 26.8 \\
\hline & & & Junior Manager & 36 & 37.1 \\
\hline & & & Non-Management & 29 & 29.9 \\
\hline \multicolumn{6}{|l|}{ ORGANISATIONS } \\
\hline Size of Workforce & Frequency & Percent & Industry Classification & Frequency & Percent \\
\hline Less than 50 & 10 & 10.3 & Manufacturing & 23 & 23.7 \\
\hline $50-250$ & 19 & 19.6 & Financial & 18 & 18.6 \\
\hline $251-500$ & 8 & 8.2 & Education & 12 & 12.4 \\
\hline $501-1000$ & 15 & 15.5 & Transport, communication & 9 & 9.3 \\
\hline $1001-2000$ & 13 & 13.4 & Wholesale and retail & 3 & 3.1 \\
\hline More than 2000 & 32 & 33.0 & Other & 32 & 32.9 \\
\hline Years Established & Frequency & Percent & & & \\
\hline Less than 1 year & 8 & 8.2 & & & \\
\hline $1-5$ years & 8 & 8.2 & & & \\
\hline $6-10$ years & 23 & 23.7 & & & \\
\hline $11-20$ years & 58 & 59.8 & & & \\
\hline
\end{tabular}

\section{Findings}

As Table 2 indicates, there is a significantly higher level of performance in of organisations that have adopted some level of HPWPs than those which have not, which is in line with findings dating back to Huselid (1995). This particularly applies to productivity improvement and, to a lesser extent, with outcomes related to the relationship of HRM with managerial practices and other organisational functions. There is also a significant difference between the means of organisations in relation to innovativeness, although this may in fact be a case of interdependence as innovativeness may be the reason why HPWPs are introduced in the first place. The appropriateness of HRM practices in relation to employee qualifications and experience, organisational location and size are also indicated by the survey.

The study does not identify any significant difference between organisations with and without HPWPs in HRM in relation to financial strength, risk-taking, competitive strength and nonmanagement employee involvement in developing HRM practices. Most respondents rated their organisation's financial status quite highly, so while financial strength gradually reduced in line with level of HPWP adoption, the difference between adoption levels was not statistically significant. This result differs from a number of studies which identify a strong link between HPWPs and strong organisational financial outcomes (Patterson et al, 1997; Wood and De Menezes, 1998; Guest et al, 2000a, 2000b) but may be explained by the high level growth phase of economic development in post-war Sri Lanka. 
Table 2: The level of variation in selected measures of performance between organisations with different levels of adoption of HPWPs in HRM

\begin{tabular}{|c|c|c|c|c|c|}
\hline & $\begin{array}{l}\text { Adoption } \\
\text { Very High* }\end{array}$ & $\begin{array}{l}\text { Adoption } \\
\text { Medium* }\end{array}$ & $\begin{array}{l}\text { Adoption } \\
\text { Low* }\end{array}$ & $\begin{array}{l}\text { No } \\
\text { Adoption* }\end{array}$ & Comment \\
\hline Financial strength & $6.80(1)$ & $6.15(1)$ & $5.86(1)$ & $5.59(1)$ & No significant difference \\
\hline $\begin{array}{l}\text { Productivity } \\
\text { improvement }\end{array}$ & $6.20(1)$ & $5.23(2)$ & $4.62(2)$ & $2.71(3)$ & $\begin{array}{l}\text { Significant difference - } \\
3 \text { subsets }\end{array}$ \\
\hline Management support & $5.20(1)$ & $5.56(1)$ & $5.33(1)$ & $3.93(2)$ & $\begin{array}{l}\text { Significant difference - } \\
2 \text { subsets }\end{array}$ \\
\hline $\begin{array}{l}\text { Alignment with } \\
\text { management style }\end{array}$ & $6.20(1)$ & $5.00(1)$ & $4.45(2)$ & $3.95(2)$ & $\begin{array}{l}\text { Significant difference - } \\
2 \text { subsets }\end{array}$ \\
\hline $\begin{array}{l}\text { Alignment of HPWPs } \\
\text { with other organisational } \\
\text { functions }\end{array}$ & $6.00(1)$ & $5.12(1)$ & $5.05(1)$ & $3.18(2)$ & $\begin{array}{l}\text { Significant difference - } \\
2 \text { subsets }\end{array}$ \\
\hline Level of innovativeness & $4.20(1)$ & $4.74(1)$ & $4.10(1)$ & $2.41(2)$ & $\begin{array}{l}\text { Significant difference - } \\
2 \text { subsets }\end{array}$ \\
\hline Level of risk-taking & $3.40(1)$ & $4.22(1)$ & $4.00(1)$ & $2.95(1)$ & No significant difference \\
\hline Competitive strength & $5.60(1)$ & $5.78(1)$ & $4.76(1)$ & $4.48(1)$ & No significant difference \\
\hline $\begin{array}{l}\text { Appropriateness of HR } \\
\text { practices for the } \\
\text { qualifications and } \\
\text { experience of employees }\end{array}$ & $5.60(1)$ & $5.00(1)$ & $4.35(1)$ & $3.34(2)$ & $\begin{array}{l}\text { Significant difference - } \\
2 \text { subsets }\end{array}$ \\
\hline $\begin{array}{l}\text { Level of involvement of } \\
\text { non-management } \\
\text { employees in developing } \\
\text { HR practices }\end{array}$ & $4.00(1)$ & $4.04(1)$ & $4.20(1)$ & $3.68(1)$ & $\begin{array}{l}\text { No significant } \\
\text { difference }\end{array}$ \\
\hline $\begin{array}{l}\text { Appropriateness of } \mathrm{HR} \\
\text { practices for location of } \\
\text { the organization }\end{array}$ & $5.60(1)$ & $4.96(1)$ & $4.60(1)$ & $3.82(2)$ & $\begin{array}{l}\text { Significant difference - } \\
2 \text { subsets }\end{array}$ \\
\hline $\begin{array}{l}\text { Appropriateness of } \mathrm{HR} \\
\text { practices for the size of } \\
\text { the organization }\end{array}$ & $6.20(1)$ & $5.31(2)$ & $4.45(2)$ & $3.20(3)$ & $\begin{array}{l}\text { Significant difference - } \\
3 \text { subsets }\end{array}$ \\
\hline
\end{tabular}

* Each cell indicates mean response; subset number in brackets

The relationships between Pfeffer's (1998) seven types of HPWPs and the selected performance measures are summarized in Table 3, which indicates the multiple regression beta scores for variation in the dependent variable (performance measure) attributed to each of the dependent variables (HPWPs). The sample includes only those organisations which have indicated that HPWPs are used in the HRM strategy. The HPWPs that are most significant to each of the performance measures (that is, have $\beta>0.180$ or $\beta<-0.180$ ) are shaded in the Table. HPWPs related to reduction of status differences and selective hiring each have the widest range of influence together with compensation, although the latter differs in that its influence is largely negative rather than positive, while team working, training and sharing information are also significant. Employment security related HPWPs had very little influence on the performance measures included in the study, and where they are significant the effect is strongly negative. Pfeffer (1998) saw employment security as essential for the success of HPWPs in that it established a foundation where employees felt motivated to contribute to higher performance outcomes. However it is also possible to argue that a high level of security can lead to apathy and disinterest in organisational advancement, which may explain the negativity associated with its influence on organisational outcomes, a situation which can be remedied by more effective manpower planning and flexibility in HRM systems (Marchington and Wilkinson, 2005). The results obtained in this study indicate that such developments may be needed within the structure of the psychological contract in employment relationships in Sri Lanka. 
Table 3: Impact of HPWPs on selected measures of organisational performance

\begin{tabular}{|c|c|c|c|c|c|c|c|c|c|}
\hline $\begin{array}{c}\text { Measures of } \\
\text { organisational } \\
\text { performance }\end{array}$ & Beta & 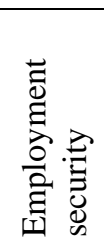 & 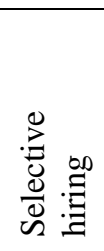 & 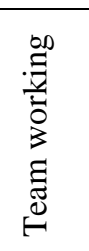 & 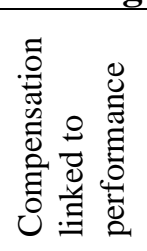 &  & 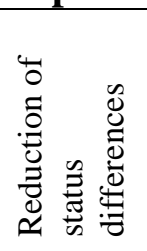 & 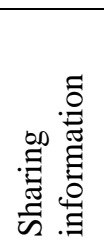 & $\mathrm{R}^{2}$ \\
\hline Financial strength & $\mathrm{B}=$ & .169 & -.009 & -.183 & .376 & .241 & -.137 & .012 & .266 \\
\hline $\begin{array}{l}\text { Productivity } \\
\text { improvement }\end{array}$ & $\mathrm{B}=$ & -.105 & .440 & -.147 & -.298 & .202 & .288 & -.018 & .430 \\
\hline $\begin{array}{l}\text { Management } \\
\text { support }\end{array}$ & $\mathrm{B}=$ & $\begin{array}{l}-.048 \\
\end{array}$ & .216 & .288 & -.181 & .343 & -.053 & -.039 & .371 \\
\hline $\begin{array}{l}\text { Alignment with } \\
\text { management style }\end{array}$ & $\mathrm{B}=$ & .021 & .343 & .151 & .229 & .377 & -.222 & -.053 & .400 \\
\hline $\begin{array}{l}\text { Alignment of } \\
\text { HPWPs with other } \\
\text { organisational } \\
\text { functions }\end{array}$ & $\mathrm{B}=$ & $\begin{array}{l}-.034 \\
\end{array}$ & -.141 & .037 & .146 & .012 & .037 & .266 & .171 \\
\hline $\begin{array}{l}\text { Level of } \\
\text { innovativeness }\end{array}$ & $\mathrm{B}=$ & -.468 & .534 & .493 & -.530 & -.033 & .630 & -.229 & .515 \\
\hline $\begin{array}{l}\text { Level of risk- } \\
\text { taking }\end{array}$ & $\mathrm{B}=$ & .165 & .093 & .273 & -.392 & .009 & .208 & .160 & .412 \\
\hline $\begin{array}{l}\text { Competitive } \\
\text { strength }\end{array}$ & $\mathrm{B}=$ & .002 & $\begin{array}{l}-010 \\
\end{array}$ & .440 & .149 & -.431 & -.094 & .242 & .143 \\
\hline $\begin{array}{l}\text { Appropriateness of } \\
\text { HR practices for } \\
\text { the qualifications } \\
\text { and experience of } \\
\text { employees }\end{array}$ & $\mathrm{B}=$ & .080 & .397 & .067 & .187 & .088 & .199 & -.026 & .657 \\
\hline $\begin{array}{l}\text { Level of } \\
\text { involvement of } \\
\text { non-management } \\
\text { employees in } \\
\text { developing HR } \\
\text { practices }\end{array}$ & $\mathrm{B}=$ & -.488 & .448 & .264 & -.352 & -.078 & .266 & -.043 & .209 \\
\hline $\begin{array}{l}\text { Appropriateness of } \\
\text { HR practices for } \\
\text { location of the } \\
\text { organization }\end{array}$ & $\mathrm{B}=$ & -.059 & .265 & -.054 & .160 & -.156 & .234 & .197 & .358 \\
\hline $\begin{array}{l}\text { Appropriateness of } \\
\text { HR practices for } \\
\text { the size of the } \\
\text { organization }\end{array}$ & $\mathrm{B}=$ & -.204 & .201 & .234 & -.114 & -.105 & .653 & .111 & .620 \\
\hline
\end{tabular}

Table 4 provides a summary of the overall impact of HPWPs on each of the performance measures. 
Table 4: Summary of HPWP influence on selected organisational performance outcomes

\begin{tabular}{|c|c|c|c|c|}
\hline Performance outcome & $\begin{array}{l}\text { Influenced } \\
\text { by level of } \\
\text { adoption of } \\
\text { HPWPs } \\
\end{array}$ & $\begin{array}{l}\text { Level to } \\
\text { which } \\
\text { influenced } \\
\text { by HPWPs }\end{array}$ & \begin{tabular}{|l|} 
HPWPs which \\
have strong \\
positive influence \\
$(\beta>0.180)$
\end{tabular} & $\begin{array}{l}\text { HPWPs which } \\
\text { have strong } \\
\text { negative influence } \\
(\beta<-0.180)\end{array}$ \\
\hline Financial strength & No & Low & $\begin{array}{l}\text { - Compensation } \\
\text { - Training }\end{array}$ & - Team working \\
\hline $\begin{array}{l}\text { Productivity } \\
\text { improvement }\end{array}$ & High & High & $\begin{array}{l}\text { - Selective hiring } \\
\text { - Training } \\
\text { - Reduction of } \\
\quad \text { status differences }\end{array}$ & - Compensation \\
\hline Management support & Medium & Moderate & \begin{tabular}{|l} 
- Training \\
- Team working \\
- Selective hiring \\
\end{tabular} & - Compensation \\
\hline $\begin{array}{l}\text { Alignment with } \\
\text { management style }\end{array}$ & Medium & Moderate & \begin{tabular}{|l} 
- Training \\
- Selective hiring \\
- Compensation
\end{tabular} & $\begin{array}{l}\text {-Reduction of status } \\
\text { differences }\end{array}$ \\
\hline $\begin{array}{l}\text { Alignment of HPWPs } \\
\text { with other } \\
\text { organisational functions }\end{array}$ & Medium & Low & \begin{tabular}{|l}
-Sharing \\
information
\end{tabular} & \\
\hline Level of innovativeness & Medium & High & $\begin{array}{l}\text { - Reduction of } \\
\text { status differences } \\
\text { - Selective hiring } \\
\text { - Team working } \\
\text { - Employment } \\
\text { security }\end{array}$ & $\begin{array}{l}\text { - Compensation } \\
\text {-Sharing } \\
\text { information }\end{array}$ \\
\hline Level of risk-taking & No & Moderate & \begin{tabular}{|l} 
- Team working \\
- Reduce status \\
differences
\end{tabular} & - Compensation \\
\hline Competitive strength & No & Low & $\begin{array}{l}\text { - Team working } \\
\text { - Sharing } \\
\text { information }\end{array}$ & - Training \\
\hline $\begin{array}{l}\text { Appropriateness of HR } \\
\text { practices for the } \\
\text { qualifications and } \\
\text { experience of } \\
\text { employees }\end{array}$ & Medium & High & $\begin{array}{l}\text { - Selective hiring } \\
\text { - Reduction of } \\
\text { status differences } \\
\text { - Compensation }\end{array}$ & \\
\hline $\begin{array}{l}\text { Level of involvement of } \\
\text { non-management } \\
\text { employees in } \\
\text { developing HR } \\
\text { practices }\end{array}$ & No & Low & \begin{tabular}{|l} 
- Teamwork \\
- Reduction of \\
status differences \\
- Selective hiring
\end{tabular} & $\begin{array}{l}\text {-Employment } \\
\text { security } \\
\text { - Compensation }\end{array}$ \\
\hline $\begin{array}{l}\text { Appropriateness of HR } \\
\text { practices for location of } \\
\text { the organization }\end{array}$ & Medium & Medium & $\begin{array}{l}\text { - Selective hiring } \\
\text { - Reduction of } \\
\text { status differences } \\
\text { - Sharing } \\
\text { information } \\
\end{array}$ & \\
\hline $\begin{array}{l}\text { Appropriateness of HR } \\
\text { practices for the size of } \\
\text { the organization }\end{array}$ & High & High & $\begin{array}{l}\text { - Reduction of } \\
\text { status differences } \\
\text { - Team working } \\
\text { - Selective hiring }\end{array}$ & $\begin{array}{l}\text {-Employment } \\
\text { security }\end{array}$ \\
\hline
\end{tabular}

Tables 3 and 4 highlight the positive effects of HPWPs on the selected performance outcomes. In addition, the negative effects of employment security and compensation should be noted. A total of $58 \%$ of employment security related outcomes are negative, with innovativeness and employee involvement in HR development significantly high. 
Compensation-related HPWPs have a lesser negative effect (42\% of outcomes) but nonetheless high in the same categories as those of employment security together with risktaking and productivity. The fact that HPWPs can have positive effects in some areas and negative in others supports the claims of Marchington and Grugulis (2000).

\section{Implications of the study}

\section{For theory}

The study provides breadth to the knowledge identifying the positive effect of HPWPs by measuring a broad range of organisational outcomes as well as carrying out the study in a developing South Asian country. Not all performance outcomes were shown to be enhanced by the use of HPWPs in HRM but those which were significantly improved included productivity, HRM-management relationships, innovativeness and appropriateness of HR practices for the qualifications and experience of employees as well as organisational location and size.

Although the study indicates a negative effect from the use of HPWPs in HRM related to security and compensation it is not being suggested that these be reduced, but rather that the relevant relationships be explored in greater depth to ascertain a greater understanding of these results.

\section{For practitioners}

The study provides managers and HR practitioners with an indication that HPWPs are not only effective in influencing organisational performance but also that certain practices have a wider sphere of influence than others, both positively and negatively. Tables 3 and 4 summarise the HPWP and performance relationships, serving as a ready guide for organisational decision makers.

The largely negative influence of employment security on outcomes contrasts with Pfeffer's (1998) perspective that it provides the foundation for the effectiveness of HPWPs. Organisations may need to more closely examine their manpower planning strategies, workplace agreements and structural flexibility in order to make their employment security systems more effective in contributing to performance outcomes.

\section{Limitations of the study}

As the study is limited in terms of geographical spread and sample size its findings must be considered in this light. It also looked at the concept of HPWPs in HRM in general terms rather than as to which strategy (best practice, best fit or configurational bundling) was used.

The selection of performance outcomes tested in the study was based mainly on those that have been identified in the literature as being important to the effectiveness of HRM practices, but also included more general organisational outcomes such as levels of productivity, innovativeness, financial strength and innovativeness. There are numerous other outcomes at different levels of specificity that also can be considered for similar analysis. 
In some instances there may be a level of interdependence between the HPWPs and the performance outcome variables which may influence the direction of their independent/dependent variable relationship.

\section{Further Study}

While this research explores some aspects of the influence of HPWPs in HRM upon performance outcomes in the Sri Lankan context there are three important areas which would merit further investigation of the topic. Firstly, there is a need to study the effect of HPWPs on additional performance outcomes. These may include outcomes applicable to organisations in general as well as those specific to particular industries or individual units. A further direction should relate to case studies of HPWPs in HRM within specific organisations or industry groups which would enable an understanding of how organisations manage HPWPs, and why the positive and negative relationships identified in this study have evolved. These would be further enhanced by longitudinal studies tracing the introduction and development of HPWPs and their effect on performance outcomes over time. More so than a cross-sectional study, they could identify the problems and benefits associated with the development of HPWPs over time and their potential life cycle.

\section{Conclusion}

This study has shown that organisations with HPWPs have overall higher levels of importance in a range of performance outcomes. Although HPWPs influence some outcomes positively they also may have negative effects upon others. The results have indicated which practices most significantly impact upon different outcomes thereby providing organisational decision makers with a guide as to how HPWPs can be employed most effectively to achieve organisational objectives.

\section{References}

Becker, B. and Huselid, M. (1998), High Performance Work Systems and Firm Performance: A Synthesis of Research and Managerial Implications, Research in Personnel and Human Resource Management, Vol. 16, pp. 53-101.

Boselie, P., Dietz, G. and Boon, C. (2005), Commonalities and contradictions in HRM and performance research, Human Resource Management Journal, Vol. 15, pp. 67-94.

Bowen, D.E. and Ostroff, C. (2004), Understanding HRM-firm performance linkages: The role of the "strength" of the HRM system, Academy of Management Review, Vol. 29, No. 2, pp. 203-221.

Boxall, P. and Macky, K. (2009), Research and theory on high-performance work systems: Progressing the high involvement stream, Human Resource Management Journal, Vol.19, pp. 3-23.

Boxall, P. and Purcell, J. (2008), Strategy and Human Resource Management (2nd ed.). Basingstoke: Palgrave Macmillan. 
Browning, V., Edgar, F., Gray, B. and Garrett, T. (2009), Realising competitive advantage through HRM in New Zealand service industries. The Service Industries Journal, Vol. 29, No. 6, pp. 741-760.

Bruce, S. (2013), Top 10 best practices in HR management for 2013, http://hrdailyadvisor.blr.com

Collings, D., Demirbag, M., Mellahi, K. and Tatoglu, E. (2010), Strategic orientation, human resource practices and organisational outcomes: evidence from Turkey, The International Journal of Human Resource Management, Vol. 21, No. 14, pp. 25892613.

Delery, J. (1998), Issues of fit in strategic human resource management: Implications for Research, Human Resource Management Review, Vol. 8, No. 3, pp. 289-309.

Fey, C.F., Bjorkman, I. and Pavlovskaya, A. (2000), The effect of human resource management practice on firm performance in Russia, International Journal of Human Resource Management, Vol. 11, No. 1, pp. 1-18.

Gould-Williams, J. and Mohamed, R.B. (2010), A comparative study of the effects of 'best practice' HRM on worker outcomes in Malaysia and England local government, The International Journal of Human Resource Management, Vol. 21, No. 5, pp. 653-675.

Guest, D.E. (1997), Human resource management and performance: A review of the research agenda, International Journal of Human Resource Management, Vol. 8, No. 3, pp. 263-276.

Guest, D.E. (1999), Human resource management: The workers' verdict, Human Resource Management Journal, Vol. 99, No. 2, pp. 5-25.

Guest, D., Michie J., Conway, N. and Sheehan M. (2000a), Employment Relations, HRM and Business Relations, HRM and Business Performance. London: Chartered Institute for Personnel and Development.

Guest, D., Michie J., Sheehan, S. and Metochi, M. (2000b), Effective People Management : Initial Findings of the People at Work Survey. London: Chartered Institute of Personnel and Development.

Guest, D., Michie J., Conway, N. and Sheehan M. (2003), Human resource management and performance, British Journal of Industrial Relations, Vol. 41, No. 2, pp. 291-314.

Guest, D., Conway, N. and Dewe, P. (2004), Using sequential tree analysis to search for "bundles" of HR practices, Human Resource Management Journal, Vol. 14, pp. 7996.

Huselid, M. (1995), The impact of human resource management: An agenda for the 1990s, International Journal of Human Resource Management, Vol.1, No.1, pp. 17-43. 
Kroon, B. and Van De Voorde, K. (2013), High performance work practices in small firms: A resource-poverty and strategic decision-making strategy, Small Business Economics, Vol. 41, pp. 71-91.

Kuvaas, B. and Dysvik, A. (2010), Does best practice HRM only work for instinsically motivated employees? The International Journal of Human Resource Management, Vol. 21, No. 13, pp. 2339-2357.

Marchington, M. and Grugulis, I. (2000), 'Best practice' human resource management: Perfect opportunity or dangerous illusion? International Journal of Human Resource Management, Vol. 11, No. 6, pp. 1104-1124.

Marchington, M. and Wilkinson, A. (2005), Human Resource Management at Work, London: Chartered Institute of Personnel and Development.

Paauwe, J., and Boselie, P. (2003), Challenging 'strategic HRM' and the relevance of institutional setting, Human Resource Management Journal, Vol. 13, pp. 56-70.

Park, H.J., Mitsuhashi, H., Fey, C.F. and Bjorkman, I. (2003), The effects of human resource management practices on Japanese MNC subsidiary performance: A partial mediating model, International Journal of Human Resource Management, Vol. 14, No. 8, pp. 1391-1406.

Pfeffer, J. (1994), Competitive Advantage through People, Boston, MA: Harvard Business School Press.

Pfeffer, J. (1998), The Human Equation: Building Profits by Putting People First, Boston, MA: Harvard Business School Press.

Ranasinghe, S. (2013), HR challenges in a developing economy: Towards multiple roles of HR professionals in a competitive business environment, In S. Ranasinghe and A. Dharmasiri (Eds), HR Challenge: Dynamics of Value Creation and Competitiveness Through People, Sri Lanka: Institute of Personnel Management.

Richardson, R. and Thompson, M. (1999), The Impact of People Management Practices on Business Performance: A Literature Review, London: Institute of Personnel Management.

Teagarden, M., Von Glinow, M., Bowen, D. et al. (1995), Toward a theory of comparative management research: An idiographic case study of the best human resources management project, Academy of Management Journal, Vol. 3B, No. 5, pp. 12611287.

Truss, C. (2001), Complexities and controversies in linking HRM with organisational outcomes, Journal of Management Studies, Vol. 38, No. 8, pp. 1121-1149.

West, M., Borrill C., Dawson, J., Scully, J., Carter, M., Anelay, S., Patterson, M. and Waring, J. (2002), The link between the management of employees and patient mortality in acute hospitals, International Journal of Human Resource Management, Vol. 13, No. 8, pp. 1299-1310. 
Wood, S. and de Menezes, L. (1998), High commitment management in the UK: Evidence from the Workplace Industrial Relations Survey and Employers' Manpower and Skills Survey, Human Relations, Vol. 51, No. 4, pp. 485-515. 